Interdisciplinary Contexts of Special Pedagogy
No. 25/2019 $\quad \begin{array}{r}\text { KAROL BIDZIŃSKI } \\ \text { Jan Kochanowski University in Kielce } \\ \hline\end{array}$

\title{
The improvement of partnership of family and school - in the light of evaluation research
}

\begin{abstract}
Karol Bidziński, The improvement of partnership of family and school - in the light of evaluation research. Interdisciplinary Contexts of Special Pedagogy, no. 25, Poznań 2019. Pp. 197-227. Adam Mickiewicz University Press. ISSN 2300-391X. DOI: https://doi.org/10.14746/ikps.2019.25.09

Humanistically oriented, qualitative educational studies allow learning about and supporting the processes of social change, including the development of schools directed towards the implementation of the idea of inclusive education. Evaluation research seems to be particularly useful for achieving this goal. The results presented in the article are a part of the extensive material collected in field research, which was conducted in the years 2015-2018 in eight schools of Świętokrzyskie Voivodeship. The aim of the study was to describe school community activity and the subjective and intersubjective structure of the meaning of entities creating space for the implementation of students' educational needs. The article presents the beliefs of parents and teachers on the educational partnership of schools and family, as well as barriers in its development, reconstructed on the basis of data originated from group discussions conducted in one of the schools that participated in the research.
\end{abstract}

KEY WORDS: school and family partnerships, inclusive education, evaluation research 


\section{Introduction}

The implementation of the idea of inclusive education consists in introducing profound changes in contemporary school and organizing educational activities in such a way that each student can find there an optimal environment for learning and harmonious development. Parents of the students can play a special role in the internal development of the school. Building a community in which school employees and parents work together on a partnership basis is one of the indicators of creating an inclusive school culture and thus an important element of implementing the idea of inclusive education ${ }^{1}$. Among the nine requirements established for the Polish school by the state, listed in the relevant regulation, 2 is the requirement "Parents are school partners". The manifestation of this partnership is the co-decision of parents in matters of the school or institution and participation in the undertaken activities, as well as the cooperation of the school with parents to support the development of children.

For many years, psychologists, sociologists, and especially educators have been studying the role of the family in educational processes and its impact on child development. Currently, in the educational considerations, the theory and practice of family and school relationships, the issues of integration of family and school educational interactions; caring-providing and educational connections; problems of democratization and humanization of family and school relationships, as well as the position of a child/student in the model of partner relationships are discussed ${ }^{3}$. Numerous studies

${ }^{1}$ Przewodnik po edukacji właczającej rozwój kształcenia i uczestnictwa w życiu szkoły, eds. T. Booth, M. Ainscow, Editor: Olimpiady Specjalne Polska, Warsaw 2011 (reedition 2012), p. 46.

2 Regulation of the Ministry of National Education of 11 August 2017 on the requirements for schools and institutions, Journal of Laws of 2017, item 1611

${ }^{3}$ A. Janke, S. Kawula, Stosunki rodziny i szkoty. Integracja i syntonia, [in:] Pedagogika rodziny: obszary i panorama problematyki, ed. S. Kawula i inni, Wydawnictwo Adam Marszałek, Torun 2006, pp. 219-262. 
have proven the existence of a relationship between family activities and student's development, and level of their school, and socialemotional skills.

In the literature on the subject, various terms for the relationship of the student's family and school can be found, namely, cooperation between parents and teachers, cooperation between family and school, acting for the child in consultation with parents and others. Parents are defined as allies of the school, teacher's partners and allies, customers, co-workers etc. It is not without significance which terms are used to describe this relationship which is important from the perspective of child/student development. Do we consider parents and teachers, or are the entire family system and all subjects of school reality, as subjects of this relationship? It seems that considering the processes of humanization and democratization of family and school relationships taking place in the area of education, it is most accurate to describe this relationship with the term partnership and to examine to what extent the actual cooperation of the student's family with the school community approaches this ideal state. "The partnership assumes a formal alliance and a contractual agreement aimed at working towards common goals and sharing the profits or benefits of mutual action" 5 . In the case of family and school, the partnership consists in establishing an equal, parent and teacher relationship based on mutual understanding and respect, in which both parties jointly make educational decisions regarding the child/student and act for their good.

However, it is worth remembering that this is an alliance of two environments important for the child development: the family system and the school as a social educational space. Mutual overlapping of the influences of these two environments on the develop-

${ }^{4}$ K. Lasater, Parent-Teacher Conflict Related to Student Abilities: The Impact on Students and the Family-School Partnership, "School Community Journal", 2016, Vol. 26, No. 2 p. 237-262, http:/ / www.schoolcommunitynetwork.org/SCJ.aspx [29 July 2018].

${ }^{5}$ J.L. Epstein, School and Family Partnerships. Report No. 6, Center on Families, Communities, Schools, and Children's Learning, Johns Hopkins University, Baltimore 1992, p. 11-14. https:/ / files.eric.ed.gov/fulltext/ED343715.pdf [23.07.2018]. 
ment of a person is well described by the systemic model developed by the creator of ecological psychology, U. Bronfenbrenner (1979). According to the assumptions of the model, "human mental development always takes place in the specific context of the relationship with the environment (-). The environment constitutes a complex system of relationships in the area of individual subsystems, as well as between them" 6 . Family and school belong to the environments closest to the child. They interact and depend on each other. Systems of environmental interactions determine the child development, but also the course of the child development affects the nature of these interactions. Disability or other reasons for which the child experiences serious learning difficulties set special requirements for them and their immediate surroundings. "The way in which a child and their closest ones meet these requirements will determine the quality of their development"7.

The theory of educational partnership of family, school and local community was developed by Joyce Epstein. In Poland, this model was popularised by $\mathrm{M} \mathrm{Mendel}^{8}$, and describing this concept, she proposed the following definitions of six types of partnership cooperation: parenting (supporting parents in their parenting tasks); communications (two-way school-home information flow); parental volunteering (activities of parents for the school); learning at home (organization of learning at home); decision making (involving parents in making decisions on children's educational matters) and collaborating with community (creating local coalitions for education and the environment). The Epstain's model verified in numer-

${ }^{6}$ Wł. Pilecka, Perspektywa systemowo-ekologiczna, [in:] Dziecko ze specjalnymi potrzebami edukacyjnymi w drodze ku dorosłości, eds. Wł. Pilecka, M. Rutkowski, Oficyna Wydawnicza Impuls, Cracow 2009, pp. 22-23.

7 Ibidem, p. 24.

${ }^{8}$ M. Mendel, Jak organizować wspótprace z rodzicami, [in:] Klocki autonomiczne w szkole, ed. M. Mendel, Gdańskie Forum Oświatowe, Gdańsk 1999, pp. 39-42.

M. Mendel, Nauczyciel z uczniem, rodzicami i lokalna społecznością. Koncepcje partnerstwa edukacyjnego, [in:] Pedagogika wczesnoszkolna - dyskursy, problemy, rozwiazania, ed. D. Klus-Stańska, M. Szczepska-Pustkowska, Wydawnictwa Akademickie i Profesjonalne, Warsaw 2009, pp. 185-223. 
ous studies has become the basis for creating family and school partnership programs in the United States. In the conducted studies, the impact of family and community involvement on student achievement was analysed; the effectiveness of various strategies for building partnerships of schools, families and communities was assessed, and the participation of parents and representatives of the local community in activities aimed at improving the quality of school work was examined?.

Family and school partnerships can be implemented at two levels: institutional one, which includes activities targeted at all student families and personal one, which is based on a direct partnership between the teacher and the specific student's family. It is particularly difficult to establish a personal partnership with a parent whose child faces serious learning difficulties, and providing support is a complex problem for the school and family. One of the possible sources of conflict may be a different understanding of the possibilities and needs of the student by their parents and teachers, as well as a lack of agreement regarding the undertaken activities. A number of barriers to establishing a family and school partnership have been identified, which can have both structural and psychological nature and be located in each of the interacting environments and at their interface ${ }^{10}$.

\section{Methodological assumptions of the presented study}

The paper presents fragmentary research results obtained under the individual project entitled Primary school as a community of activi-

${ }^{9}$ F.L. Van Voorhis, M.F. Maier, J.L. Epstein, Ch.M. Lloyd, The Impact of Family Involvement on the Education of Children Ages 3 to 8: A Focus on Literacy and Math Achievement Outcomes and Social-Emotional Skills, MDRC. 2013. http://dev.mdrc. org/sites/default/files/The_Impact_of_Family_Involvement_FR.pdf [10 May 2019].

${ }^{10}$ S.L. Christenson, The Family-School Partnership: An Opportunity to Promote the Learning Competence of All Students. "School Psychology Review", 02796015, 2004, Vol. 33, no. 1, pp. 83-104. 
ties and subjective and intersubjective meanings of entities creating space for the implementation of special educational needs of students (Szkota podstawowa jako wspólnota działania oraz subiektywnych $i$ intersubiektywnych znaczeń podmiotów kreujących przestrzeń realizacji specjalnych potrzeb edukacyjnych uczniów). The project was implemented in the years 2015-2018, an in-depth analysis of the obtained material is currently being performed.

In qualitative research, interpretative orientation was adopted, constructivist grounded theorizing according to Kathy Charmaz ${ }^{11}$. The sociological origin of grounded theory directs the researcher first and foremost to what can be called the "supra-individual dimension of reality". A specific school as a "social system settings" is a good place to conduct research, and collect data from "social units" (the educational space of this school, its symbolic, intersubjective, subjective dimension). The exploration of the sociological dimension of educational phenomena allows a better description of the complexity of educational situations and forms the basis of humanistically oriented educational research ${ }^{12}$.

The aim of the project was to describe and attempt to explain the complexity of the educational situation in the public primary school space, in which students with different/special educational needs complete their compulsory education.

The analysis allowed highlighting and explaining both fixed patterns and stability in the activities undertaken by the school supporting students in satisfying their needs, as well as internal change processes initiated to respond to new challenges and enable learning about the individual and intersubjective sphere of meanings constructed by the "actors" of the studied educational space (students, parents, teachers, school specialists, headmaster), exposure of contradictions, ambivalence and lack of connections.

${ }^{11}$ K. Charmaz, Teoria ugruntowana. Praktyczny przewodnik po analizie jakościowej, PWN, Warsaw 2009.

12 D. Kubinowski, Jakościowe badania pedagogiczne. Filozofia. Metodyka. Ewaluacja, Wydawnictwo Uniwersytetu Marii Curie Skłodowskiej, Lublin 2010. 
The study covered 8 primary schools, in which activities of the nature of internal evaluation with the researcher as a critical friend were conducted in consecutive two years. The subject of the evaluation was the fulfilment by the school of the requirement: The school or institution supports the development of students, taking into account their individual situation.

Evaluation research conducted in order of action allowed learning about the organization, implementation as well as internal and external conditions of psychological and educational support, activities in the field of educational support and support provided to students with special educational needs in public schools. Thanks to adopting specific criteria and indicators, the attempt to assess the effectiveness of assistance/support activities was possible. The results obtained in the study became the starting point for team formulation of postulates in the form of recommendations: reports for schools, indications for working with students (study of individual cases) $)^{13}$.

Moreover, the research constituted an attempt to discover the values present in everyday practice; by starting a hermeneutic discourse and common learning of the sense of undertaken actions, recreating the subjective and intersubjective structure of meanings (agreeing positions), dialogue of all interested parties (understanding one's future, support), empowering the implementers.

\section{Intersubjective significance of family and school partnership, analysis of research results}

The article describes the beliefs of parents and teachers on the educational partnership of schools and family, as well as barriers in its development, reconstructed on the basis of data originated from

${ }^{13}$ K. Bidziński, Naukowo-metodyczne wspieranie rozwoju szkoły - urzeczywistnianie idei edukacji włączającej, [in:] Człowiek w przestrzeni edukacyjnej wspótczesnego świata, ed. E. Asmakovets, S. Koziej, Wydawnictwo Uniwersytetu Jana Kochanowskiego, Kielce 2017, pp. 120-132. 
two group discussions conducted in one of the schools of Świętokrzyskie Voivodeship that participated in the project.

Data were obtained during:

- A focus group interview, FGI) ${ }^{14}$ conducted among parents of students of the second stage of education;

- discussions with the use of metaplan, with teachers, headmasters and school specialists.

The focus group interview was a classic single session in which a group of ten parents of students from grades IV-VI participated. They were people who accepted the invitation to participate in the discussion about opportunities and limitations in the development of family and school partnership in activities for students. Parents participating in the meeting know one another well because they have been accompanying their children at the consecutive stages of education for several years. Prior acquaintance of the participants and the community of goals made it easier to discuss topics that are not discussed in a group of unknown people. This was possible thanks to the high sense of security and openness characterizing this parent group. In the focus study, an important role was played by moderators who, thanks to their actions, dynamised the group process and minimised negative group effects ${ }^{15}$ In the session the role of a moderator was played by a guidance counsellor, a person known to parents, recognised and trusted, and a researcher who has the competence to moderate the group process.

The second source of information presented in the article was a discussion with the use of a metaplan about family and school partnership in educational activities. The classic form of the method was adopted, in which the respondents, working in teams, answered four questions: How it is? How should it be? Why is it not as it should be? What should be done to make it as it should be? For answering the first question, data collected in previous evaluation

14 J. Lisek-Michalska, Badania fokusowe. Problemy metodologiczne i etyczne, Wydawnictwo Uniwersytetu Łódzkiego, Łódź 2013, pp. 14-23.

15 Ibidem, p. 37. 
activities was used (e.g. data from focus discussions and questionnaire surveys conducted among parents of children of grades IV-VI).

The basis of the discussion in both groups was the J.L. Epstein's partnership model, in which the following areas of cooperation were distinguished: parenting, communications, parental volunteering, learning at home, decision making and collaborating with community ${ }^{16}$.

The collected material has been transcribed and coded ${ }^{17}$. Categories were created, which were ordered in the form of identified impediments to partnership and identified causes of difficulties. Partnership development directions created by the team were also presented.

As it results from the relationships between teachers and parents, their mutual contacts usually proceed in a way that is satisfactory for both parties, however, the discussion focused primarily on identifying barriers in building a school and family partnership, and searching for new forms of cooperation.

The results are of individual nature and cannot be generalised, but they illustrate some problems arising in the area of partnership and the way of their interpretation by school entities of parents and teachers.

\section{Parenting}

In group work, the following understanding of this area was adopted.

Parenting, is an area of cooperation between family and school, which involves providing various forms of support to parents and families in order to create an optimal home environment for developing children. This is done mainly by helping parents to broaden their knowledge and improve parental skills needed to understand children's needs and provide them with healthy and safe development conditions.

\footnotetext{
16 J.L. Epstein, School..., op. cit., pp. 11-14.

17 K. Charmaz, op. cit.
} 
Table 1. Strong and weak sides of family and school partnership in the area of "parenting"

\begin{tabular}{|c|c|}
\hline \multicolumn{2}{|c|}{ PARENTING } \\
\hline STRONG SIDES & WEAK SIDES \\
\hline $\begin{array}{l}\text { - Parents can count on advice from } \\
\text { teachers, school specialists, headmas- } \\
\text { ters regarding raising a child and or- } \\
\text { ganizing learning at home. } \\
\text { - Many teachers and school specialists } \\
\text { have extensive psychological and ped- } \\
\text { agogical knowledge, thanks to which } \\
\text { they can provide valuable advice to } \\
\text { parents of students. } \\
\text { - Many teachers and parents managed } \\
\text { to establish a mutual partner relation- } \\
\text { ship. } \\
\text { - Parents have access to the Internet and } \\
\text { through the school website can use } \\
\text { a rich set of educational materials on } \\
\text { effective parenting. }\end{array}$ & $\begin{array}{l}\text { - Lack or delayed reaction of the school } \\
\text { and other institutions to manifesta- } \\
\text { tions of parental neglect or problems } \\
\text { experienced by the child and family. } \\
\text { - Parents of students experiencing edu- } \\
\text { cational or learning problems usually } \\
\text { avoid contact with the school. } \\
\text { - Not all parents want to benefit from } \\
\text { the help proposed by the school to } \\
\text { improve their parenting and solve ed- } \\
\text { ucational problems. } \\
\text { - Sometimes the nature and severity of } \\
\text { family problems considerably exceeds } \\
\text { the possibilities of school help. }\end{array}$ \\
\hline
\end{tabular}

Source: own research

Forms of cooperation used in school in the area of "parenting":

- parenting interactions, which aim to shape students' respect for their parents,

- individual advice for parents of students regarding solving everyday parenting problems,

- systematic provision of information to parents about the didactic and educational situation of their children,

- meetings of students' parents with specialists from outside the school,

- popularising educational and informational materials for parents on effective parenting, through various media,

- informing parents about various non-school forms of help to improve parenting,

- annual organization of consultation points of: probation officer, social worker of the City-County Social Welfare Centre (MGOPS) (representing the municipal team for the prevention 
of domestic violence, an addiction therapist or a mediator of the District Family Social Service Agency (PCPR)).

Strong and week sides of partnership in this area, selected in discussions, are listed below.

Conclusions formulated by the team to improve partnership in the area of "parenting"

- What is needed is even greater than before common concern of teachers and parents to build a partner relationship. The shared belief in the common goals and values may serve this purpose (for both entities, the child and their optimal development are the essence and sense of cooperation).

- Meetings of parents with school and non-school specialists should be made a natural situation that involves all parents, not just those who experience educational difficulties. Plan together a strategy for activities that support the optimal development of each student. It is good if students also actively participate in these meetings.

- Systematic information for parents about school and non-school forms of parenting improvement, encouraging them to use this form of support.

- Appreciate, more than before, parenting effort, show parents of the students great understanding and provide them with support. Appreciate especially those parents who are critical partners and very involved in the matter of child education.

- Quickly react to parental neglect by starting school or non-school interventions.

- Show parents the impact the family situation has on the child's educational achievement, help recognize barriers on the family side and support their elimination.

According to conversations with teachers and parents of students, public awareness of the importance of parenting in supporting child development is increasing. This is evidenced by the statements of parents in which they declare readiness to develop educational competence and signal the need to look for methods to optimise the educational role of the home environment. A certain group of parents perceive in school a natural ally in building effec- 
tive parenting and turn to teachers and school specialists for help in solving educational problems. However, according to teachers' statements, the school often does not have sufficient potential to effectively support parents. However, the biggest problem is a fairly large group of parents who, despite serious life and upbringing difficulties, do not turn to school for support and reject any forms of help.

\section{Communications}

In group work, the following understanding of this area was adopted.

Communications, this type of cooperation focuses on all forms of searching for an effective, two-way flow of information between the school and home, in the scope of the school's curriculum offer and progress in the development of children.

In the school, numerous forms of two-way communication are used:

- general meetings in classrooms,

- individual meetings of a school representative with a parent,

- open school, meetings during which a parent can meet with all school staff involved in education,

- prophylactic parent teacher meetings, cyclical training for parents conducted by external specialists,

- problem-related meetings, initiated by parents or a form master, which concern a form problem, or a problem involving more than one student. It is often an opportunity to establish a common strategy of actions,

- librus system, an electronic grade book, contains various options for informing parents about learning outcomes and attendance (e.g. SMSInfo service),

- information for parents posted on information boards in the area of school, intended for students of different age groups, 
- informing about individual successes of students, regularly, every semester, the board at the entrance is used to promote students achieving the highest academic achievement.

- information for parents posted on the school's website.

Strong and week sides of partnership in the area of communications, selected in discussions, are listed below.

Table 2. Strong and weak sides of family and school partnership in the area of "communications"

\begin{tabular}{|c|c|}
\hline \multicolumn{2}{|c|}{ COMMUNICATION FAMILY - SCHOOL } \\
\hline STRONG SIDES & WEAK SIDES \\
\hline $\begin{array}{l}\text { - Teachers are characterised by a good } \\
\text { knowledge of the local environment, } \\
\text { teachers - parents contacts are per- } \\
\text { sonal. } \\
\text { - Many effective forms of parent- } \\
\text { teacher communication have been de- } \\
\text { veloped. } \\
\text { - New communication opportunities are } \\
\text { continuously searched for, also using } \\
\text { new technologies (electronic grade } \\
\text { book, school website with a rich set of } \\
\text { educational and informational materi- } \\
\text { als). } \\
\text { - Honesty and reliability in providing } \\
\text { information about the child. } \\
\text { - Mutual trust of parents and teachers } \\
\text { (not applicable to all parents). } \\
\text { - Focus on the successes of students } \\
\text { (parents are happy to receive positive } \\
\text { information about their child). } \\
\text { - Parents commonly have access to the } \\
\text { Internet and often learn about school's } \\
\text { activities through the website. }\end{array}$ & $\begin{array}{l}\text { - The attendance of parents at meetings } \\
\text { is various (sometimes only } 50 \% \text { of } \\
\text { parents are present). The absence of } \\
\text { parents means that it is impossible to } \\
\text { adopt solutions acceptable to every- } \\
\text { one. } \\
\text { - Teachers do not always want to listen } \\
\text { to parents' opinion. } \\
\text { - Sometimes the parents of the students } \\
\text { do not reveal the problems to the form } \\
\text { master, hide the difficulties and their } \\
\text { causes. } \\
\text { - In school practice, meetings with } \\
\text { parents related to the learning or be- } \\
\text { haviour difficulties of the child domi- } \\
\text { nate. } \\
\text { - The initiator of the meetings is usually } \\
\text { school, parents rarely signal the need } \\
\text { for conversation. } \\
\text { - Discussing the student's issues can be } \\
\text { superficial and is accompanied by } \\
\text { rush and indifference or is very emo- } \\
\text { tional with elements of verbal aggres- } \\
\text { sion. } \\
\text { - A certain group of parents does not } \\
\text { use modern information carriers. }\end{array}$ \\
\hline
\end{tabular}

Source: own research 
Conclusions formulated by the team to improve partnership in the area of "communications"

- Both parties, parents and teachers, should demonstrate even greater communication mindfulness in building mutual authority in the eyes of the child/student.

- The basis of effective cooperation parents - teachers is honest and open communication, skills in effective communication and organization of group work should be improved.

- Comments on mutual relationships should be passed directly to each other, and difficult matters should also be discussed.

- It is necessary to ensure appropriate conditions, in which the parent is informed about the difficult behaviour of their child (preferably during individual conversations, at the right time and place).

- Certain educational problems of students, after obtaining the consent of their parents, should also be discussed in the presence of other parents from a given form, so that they understand better the didactic situation (e.g. differences in assessing students with dyslexia).

- It is worth looking for a new formula for organizing meetings with parents, abandoning traditional form meetings for meetings in a less formal atmosphere.

- If this is not possible "building a fully cooperating parent group", it is worth focusing the effort on forming good, safe relationships of the form master with each parent individually. Group meetings should be limited to the necessary minimum, and more time and energy should be dedicated to the individual contact teacher - parent.

- It is necessary to look for more ways to persuade some parents to attend school meetings and increase their activity in discussing their child's problems.

- Greater consequence of parents and teachers when implementing jointly agreed arrangements concerning students is necessary.

- It is expedient to involve students, especially older students more closely, in parents' and teachers' conversations about the school situation.

- Meetings with specialists from outside the school require very good organisation, proper selection of the subject (important matters rele- 
vant for parents), appropriate level of speakers (specialist, but also a person who can organise a proper meeting); ensuring full prior notification of parents about the meeting (its date, duration, issues raised). It may be worth collecting a declaration of readiness to attend meetings from parents before the meeting. If the parents do not declare their participation, it is better to quit organizing the meeting.

- It is worth publishing a school newsletter for parents and sending it online (via e-mail or to download on the website). The newsletter could contain information about current events, advice for parents, etc.

- It can facilitate contact between parents and school staff via a website (e.g. online question box; parent discussion forum; chat with the headmaster).

Effective communication is an essential element of successful partnership and affects its quality. Care for communication efficiency should be shared by both partners, but teacher as a professional should demonstrate more responsibility. They should, thanks to the use of communication skills, adapt their style (level of openness, confidence, choice of vocabulary) to the needs and capabilities of a partner.

The attempt to organize parent teams so that they over time become a kind of support group, a place where one can speak openly about the experienced difficulties, counting on support in various dimensions, requires form masters to possess further competence. These are: the ability to moderate group work, understand group mechanisms, methods to support the group process to lead the group to the cooperation phase (high sense of security, high openness, acceptance, readiness to cooperate). According to teachers' opinions, not all parent teams are ready to take on this challenge. In such cases, it is better to create a support group only for interested parents.

An interesting idea is to invite students to the teacher-parent discussion. Thanks to this, the student could feel more subjectively, their responsibility for the obtained results and the help obtained from adults would increase. Thanks to a direct meeting of all interested persons, communication could be more open and honest. 
A child in the presence of adults who are important for them could talk about both successes and difficulties experienced, seek understanding and ask for help and support.

\section{Student's learning at home}

In group work, the following understanding of this area was adopted.

Learning at home, this type of partnership comprises providing parents with information and ideas, including helping children with homework and all after-school activities related to the implementation of the school curriculum, but also creating opportunities for children to participate in valuable educational experiences (developing interests). The school suggests parents how they can help their children organise learning at home, provides information on developing children's skills which facilitate learning and methods to deal with limitations and encountered difficulties.

Table 3. Strong and weak sides of family and school partnership in the area of "learning at home"

\begin{tabular}{|c|c|}
\hline \multicolumn{2}{|c|}{ STUDENT'S LEARNING AT HOME } \\
\hline STRONG SIDES & WEAK SIDES \\
\hline $\begin{array}{l}\text { - The vast majority of parents is inter- } \\
\text { ested in the educational situation of } \\
\text { their children and a relatively large } \\
\text { group of parents systematically coop- } \\
\text { erate with the school. } \\
\text { - Parents can count on advice from } \\
\text { teachers, school specialists, headmas- } \\
\text { ters regarding raising a child and or- } \\
\text { ganizing learning at home. } \\
\text { - A large group of students is covered } \\
\text { by psychological and educational help. }\end{array}$ & $\begin{array}{l}\text { - Parents sometimes do not know how } \\
\text { to help a child learn, in the following } \\
\text { years of education the problem in- } \\
\text { creases. } \\
\text { - Some parents have unrealistic expec- } \\
\text { tations of the school and the child as } \\
\text { a student. } \\
\text { - Some parents have little knowledge } \\
\text { about the curriculum, requirements } \\
\text { standards, and assessment methods. } \\
\text { - Numerous children must attend addi- } \\
\text { tional language classes and private } \\
\text { lessons of other subjects. }\end{array}$ \\
\hline
\end{tabular}

Source: own research 
The following forms of activity are used in school to organize student's learning at home.

-Parents are obliged to help children do their homework, control their preparation for classes.

-Parents' task is to provide children with necessary accessories and didactic aids.

-The school day room relieves parents of the need to organise learning at home, many students do their homework during the day room classes, under the supervision of teachers.

-There is peer support at school, but the youngest children need parental involvement, e.g. bringing a child to such a lesson when they leave school earlier and this is not practised.

Strong and week sides of partnership in this area, selected in discussions, are listed below.

Conclusions formulated by the team to improve partnership in the area of "student's learning at home"

- Conduct classes for parents on effective ways to organise students' learning at home.

- Develop together, with the participation of the student, parent, form master and teacher of a given subject, a common strategy to provide help in learning a given subject. Prepare appropriate materials for the student, which facilitate their homework, give instructions to parents how to support the student in catching up.

- Contribute together to the increase of the students' educational aspirations, show them the value of school education, develop motivation and focus on school tasks.

- Appreciate the effort of children to try to overcome school difficulties, even if it does not bring the expected results.

- Individualise the tasks set for students even more clearly, adapt the requirements to the capabilities of students.

- Do not compare individual learning outcomes. Limit the presentation of differences between the results achieved by children (refrain from comparing the average of grades for classes, for students).

- Appreciate other, not only didactic, successes of students. 
- Reduce the amount of given homework.

- Adapt the degree of difficulty of given homework to the skills and abilities of individual children.

Contemporary school is still looking for effective ways to support parents in organising learning at home for their children. The traditional understanding of how to implement this role is changing. In the past, parents were expected to adopt the role of "a home teacher", whose task was to ensure that children were carefully prepared for school lessons by doing so-called "homework" and acquiring appropriate knowledge. Correct fulfilment of these tasks required parents to have rich interdisciplinary school knowledge and didactic skills. These expectations were unrealistic and many parents did not manage to perform these tasks or gave up their practice. Nowadays, the understanding of the role of parents in organising homework for their children is changing. It is assumed that the school should be a place of the main educational activity of the child, and the home space should be a sphere of rest, recreation and developing extracurricular interests. Currently, a parent is expected to perform mainly a function of motivating and inspiring a child to undertake various activities, which have educational value. He will become an ally of a child in organizing the learning process, a source of support in overcoming school difficulties, and an organiser of extracurricular learning space.

As the discussion shows, a large group of parents is well oriented in the child's school situation, is interested in the tasks they undertake, knows their strengths, analyse obstacles and limitations, appreciate the effort and enjoy success, and skilfully support their child in difficult situations. These parents use the advice and tips from the form master and other teachers, they look for effective ways of motivating the child and organising extramural educational experiences.

According to the participants of the discussion, many parents still traditionally understand their role as organisers of learning at home for their children and encounter serious difficulties in its prac- 
tice. These people, using inefficient ways of organising learning, based on personal school experience, duplicate these strategies and unconsciously obstruct their children from carrying out school tasks. A serious mistake of a certain group of parents is that they excessively help or completely relieve their child of homework and thus release them from responsibility for school results.

Some parents complain that they are unable to provide substantive assistance to children in performing school tasks and do not know how to motivate them to work independently. Every year, they experience increasing difficulties in organizing learning at home for children and over time they abandon this task.

Among a certain group of parents, there is a belief that educational success is not possible without organizing specialized, extramural didactic support for the child. These parents decide to pay for additional language classes and private lessons of other subjects.

Another group of parents is characterised by a total lack of interest in child education and low educational aspirations.

To summarise, parents need more information about the child's cognitive possibilities and limitations, their motivation and educational aspirations, but at the same time data on the essence of the learning process and its psychological and sociological conditions, which will allow a more complete understanding of the school situation. The belief of all: students, parents and teachers that experiencing learning difficulties is something natural. They should discuss them calmly, searching together for their sources and ways to overcome. Particular attention should be paid to identification of causes of educational difficulties of students inherent in the family environment and manners of conducting school education. Parents and teachers have the greatest impact on eliminating these factors. It is worth undertaking an open conversation between teachers and parents about family and school conditions of the learning process. It is necessary to consider together what parents and teachers can do to become more effective allies of learning children. 


\section{Decision making of family and school}

In group work, the following understanding of this area was adopted.

Decision making, this type includes involving parents in deciding about all matters related to school life and developing parental representation.

Table 4. Strong and weak sides of family and school partnership in the area of "decision making"

\begin{tabular}{|c|c|}
\hline \multicolumn{2}{|c|}{ DECISION MAKING } \\
\hline STRONG SIDES & WEAK SIDES \\
\hline $\begin{array}{l}\text { - Parents' comments regarding the or- } \\
\text { ganization of school learning are taken } \\
\text { into account by the headmaster and } \\
\text { teachers. } \\
\text { - Parents decide on all educational and } \\
\text { support activities addressed to their } \\
\text { child. } \\
\text { - Parents approve the Individual Educa- } \\
\text { tional and Therapeutic Program } \\
\text { (IPET) and other programs designed } \\
\text { for their children. } \\
\text { - A certain group of parents got in- } \\
\text { volved in the work of bodies repre- } \\
\text { senting parents (form trios). } \\
\text { - A certain group of parents gets in- } \\
\text { volved in providing opinions on } \\
\text { school documents (curricula). }\end{array}$ & $\begin{array}{l}\text { - Parents are not always involved in the } \\
\text { work of educational teams planning } \\
\text { a strategy to help in learning, as well } \\
\text { as seeking and eliminating the causes } \\
\text { of difficulties. } \\
\text { - Many parents avoid participating in } \\
\text { the work of bodies representing par- } \\
\text { ents (parent's association). } \\
\text { - Low parent attendance at meetings. } \\
\text { - The school not sufficiently recognizes } \\
\text { the possibilities of parental support. }\end{array}$ \\
\hline
\end{tabular}

Source: own research

The following forms of decision making were listed:

- the school invites parents to work in school bodies such as a parent's association or form trios;

- some parents take part in planning school work (upbringing and preventive program);

- parents take part in the work of problem solving and advisory teams; 
- parents make important decisions about children's education and therapy;

- parents of students from the same form participate in planning special events, trips.

Strong and week sides of partnership in this area, selected in discussions, are listed below.

Conclusions formulated by the team to improve partnership in the area of "decision making"

- Make parents aware of their rights to influence the functioning of the school, both in terms of curricula and organization.

- Together with parents, define the limits of their influence on educational decisions regarding their child and school policy.

- Appreciate parents who get involved in the work of problem solving teams.

- Create more opportunities to undertake decision-making activities and provide parents with the skills they need.

For many decades, parents had not been treated as equal partners of the school, their influence on the organization of didactic and educational processes was severely limited by the state. It was only after the systemic transformation in our country that the provisions regarding the participation of parents in decision-making processes were changed. It takes time for parents to learn and appreciate the rights to decide on the program and organizational functioning of the school. Greater parent participation in planning the school's educational policy brings hope for their greater responsibility and concern for the school's future.

\section{Volunteering}

In group work, the following understanding of this area was adopted.

Volunteering, includes all activities aimed at acquiring and organizing help and support of parents for children studying at school, their teachers and the school as an institution. 
In the study school, volunteering takes the following forms:

- financial and material support of the school by parents,

- parents' participation in organizing and conducting school trips, special events,

- participation of parents as experts during certain lessons at school or during trips (e.g. to the parent's place of work),

- cleaning works in the classroom,

- other, depending on the needs, considering parents' competence, e.g. legal advice, environmental lobbying for the school.

Strong and week sides of partnership in this area, selected in discussions, are listed below.

Table 5. Strong and weak sides of family and school partnership in the area of "volunteering"

\begin{tabular}{|c|c|}
\hline \multicolumn{2}{|c|}{ VOLUNTEERING } \\
\hline STRONG SIDES & WEAK SIDES \\
\hline $\begin{array}{l}\text { - A large group of parents, especially of } \\
\text { younger children, is eager to engage } \\
\text { in various form and school activities. } \\
\text { - Parents have a variety of personal and } \\
\text { material resources that can serve the } \\
\text { school. }\end{array}$ & $\begin{array}{l}\text { - A certain group of parents avoids } \\
\text { school activities. } \\
\text { - School expectations towards parents } \\
\text { can sometimes be difficult to fulfil. }\end{array}$ \\
\hline
\end{tabular}

Source: own research

Conclusions formulated by the team to improve partnership in the area of "volunteering"

- Inviting parents to get involved in the school activities requires a good orientation in the resources they have.

- The school's expectations for parents should be clearly defined.

- It is necessary to create conditions for parents to be able to propose forms of activities for the school according to their possibilities.

Parents are perceived by teachers/form masters as an important source of support. Teachers count on parents as a source of infor- 
mation about a child, they need their help in planning and practising educational activities. It is important that parents have the opportunity to perform various activities for the school and be appreciated for undertaking this effort.

\section{Collaborating of school and family with community}

In group work, the following understanding of this area was adopted.

Collaborating with community, this type of cooperation between school and parents includes all forms aimed at recognizing and integrating remedial actions and services provided by the local community for schools, families and children. The school helps families in obtaining information about institutional resources of the local community, which can help improve home conditions and facilitate children's learning and development.

Table 6. Strong and weak sides of family and school partnership in the area of "collaborating with community"

\begin{tabular}{|c|c|}
\hline \multicolumn{2}{|c|}{ COLLABORATING WITH COMMUNITY } \\
\hline STRONG SIDES & WEAK SIDES \\
\hline $\begin{array}{l}\text { - In the school environment there are } \\
\text { many institutions working for the } \\
\text { child and their family. } \\
\text { - The school effectively cooperates with } \\
\text { various institutions working for the } \\
\text { child and their family, helps parents in } \\
\text { establishing cooperation and coordi- } \\
\text { nates support activities. }\end{array}$ & $\begin{array}{l}\text { - Parents sometimes reject the offer of } \\
\text { specialist help, e.g. support from the } \\
\text { employees of psychological and peda- } \\
\text { gogical counselling centre, social assis- } \\
\text { tance. } \\
\text { - A long waiting time for help from } \\
\text { some institutions, e.g. to obtain a deci- } \\
\text { sion or opinion in a psychological and } \\
\text { pedagogical counselling centre. } \\
\text { - Hindered flow of information between } \\
\text { the school and various institutions } \\
\text { working for the child and their family. }\end{array}$ \\
\hline
\end{tabular}

Source: own research 
Cooperation in this area takes the following forms:

- mediation between the family and institutions supporting the child's education (psychological and pedagogical counselling centre, mental health outpatient clinic),

- mediation between family and social welfare institutions (District Family Social Service Agency (PCPR), City-County Social Welfare Centre (MGOPS), judicial institutions (family court, probation officer),

- mediation between family and non-school educational institutions (cultural centre, sports club).

Strong and week sides of partnership in this area, selected in discussions, are listed below.

Conclusions formulated by the team to improve partnership in the area of "collaborating with community"

- In the case of students with a complex didactic and educational situation, early and quick specialist diagnosis is needed. Parents of these students should be encouraged to undergo examinations in a psychological and pedagogical counselling centre and inform the school about the results of the diagnosis.

- Care should be taken to update specialist student information at the appropriate time (current opinion). In the event of a change in the student's situation, e.g. the intensification of the student's difficulties, new circumstances in their life, apply for a diagnosis without waiting for the customary two years between consecutive tests.

- In the case of complex family problems, it is necessary to build a coalition of various specialist institutions working for the child and the family, and quickly take coordinated intervention measures.

- Strengthening cooperation with the environment (parents, supporting institutions). Creating a local network of institutions, and organizations working together with the school for the child and their family. Establishing in-depth cooperation.

The search for a model of local collaboration for the child and their family is underway. In this model, the school could be a central point where all activities are combined. Currently, it is expected 
that various institutions from the local environment, in cooperation, will support school and family in the performance of caring and educational tasks.

Based on the analysis of the statements of teachers and parents of students, factors that hinder building a family and school partnership were identified. The barriers selected in the study were combined into the following categories, based on their sources.

Barriers on the side of the student's family hindering partnership building:

- Lack of time experienced by many parents, absorbing parents' professional activity (work abroad, shift work, overtime work), domestic and family responsibilities (caring for younger children and others).

- A certain group of families experiences very serious problems in the form of: financial insufficiency, chronic illness of a family member, social maladjustment (alcoholism, domestic violence), neglect of emotional needs of children and others. It includes families covered by the "Blue Card" procedure, supervision of a probation officer, family assistance, using various forms of support, but also those that hide internal problems and do not use institutional support.

- A small group of parents experiences digital exclusion, those people do not use modern information and communications technologies and are thus deprived of access to relevant information about education transmitted in this way.

- In the case of one family (a bicultural family), a specific style of upbringing caused by cultural differences and specific parental attitudes were identified.

Barriers on the side of the school and education system hindering partnership building:

- The incidental and intervention nature of the parents' interaction with the form master and school specialists prevails, the action is taken only in response to a serious crisis.

- A deficiency of teacher's communication skills and support of group processes in parental teams. 
- Lack of competence of the school staff and legal and organizational possibilities to undertake specialist support activities addressed to the family system of the student being in crisis. Some parents expect the school to be ready to undertake such interventions.

- Lack of organizational solutions to establish and continue systematic cooperation between the school and various institutions acting for the child and their family.

- Hindered flow of information on the student's family situation and actions taken by various institutions for the benefit of the child and their family (e.g. the problem of personal data protection).

- Lack of full recognition by the school of the resources and possibilities of parents to undertake activities for the school.

Beliefs and emotional attitudes of a certain group of parents about cooperation with school hindering partnership building:

- Underestimation or overestimation by parents of school as a source of support in situations of experiencing serious family problems.

- Parents' belief that a visit to an non-school specialist is necessary only if the child experiences very serious educational difficulties.

- Parents' beliefs that their opinions or postulates regarding school activities will not be considered by teachers and headmasters.

- Beliefs of a certain group of parents that their commitment to school is not needed or is not possible.

- A belief that the parents' interest in the course of the child's education and its effects is not welcomed by teachers and the headmaster.

- The reluctance and distrust of a certain group of parents to school as an institution, which may be the result of previous unfavourable experiences (including those from school times).

- The use of help and advice is associated by some parents with acknowledgement of their upbringing failure and thus the source of experiencing shame. 
- Reluctance of some parents to take responsibility for decisions regarding their child's education and school work.

- Fear that teachers perceive the parents' great involvement in the child's affairs as an attempt of excessive interference in the school's activities.

Beliefs and emotional attitude of a certain group of teachers hindering the establishment of a partnership with parents:

- Fear of critical assessment on the part of parents regarding undertaken educational activities.

- A belief that a certain group of parents is too demanding towards the school.

- Expectation of parents, not taking into account their individual resources, that they will professionally help their children with homework.

- Lack of trust in some parents, showing distance with them.

- Feelings of pity and powerlessness towards families that neglect the needs of children.

- Feeling of loneliness and helplessness in the face of complicated family problems of students.

\section{Summary}

The idea of building a partnership between family and school presented in the paper is not new. It has long been known that teachers should have a good understanding of their students' family environment and include family and environmental learning contexts in their activities. It is expected from parents and teachers to become partners of their children in the learning process. However, this postulate is now gaining special significance in connection with the school's ambitious task of enrolling all children in a public school and organising and performing personalised education. Creating education tailored to the student is only possible in a partner alliance with their family, based on the resources of the local environment, with the high involvement of all school staff. 
During the research process, factors conditioning the implementation of family and school partnership in activities for the benefit of child development were identified. The external and internal conditions of parents and teachers relationships in creating the partnership were determined.

External conditions of a relationship.

- The cultural context of the importance of family and education for human development, including various concepts of mutual influence of both environments (the perspective of separate, sequential, systemic impact and the perspective of overlapping zones of influence $\left.{ }^{18}\right)$.

- Legally guaranteed (the Constitution ${ }^{19}$, the Educational Law Act $^{20}$ and others) dominant/superior role of the family in raising a child.

- The Polish education system provides support of school for the educational role of the family; school's statutory task is to cooperate with the student's family and the local community ${ }^{21}$.

- Schools have developed various forms of implementing partnerships (in terms of supporting parenting, mutual communication, organization of learning at home, decision making, parental volunteering and collaboration of the family and school with the local community 22 ). Constant search for new solutions in this area is underway.

- Systemic and organizational solutions require various institutions working for the child and their family to establish close cooperation with the school.

- Parents and teachers are limited by time and available environmental and individual resources in the creation of partnerships.

18 J.L. Epstein, School..., op. cit., pp. 8-9.

19 The Constitution of the Republic of Poland, art. 48, Journal of Laws of 1997, no. 78 , item 483 as amended.

20 The Educational Law Act, Journal of Laws of 2017 item 59 as amended.

21 Ibidem.

22 J.L. Epstein, School..., op. cit., pp. 11-14. 
Internal conditions of a relationship:

- Community of values; the best interests of the child and their optimal development are most important for the family and school. Awareness of the community of values can provide a solid foundation for building a partnership.

- Different, sometimes contradictory understanding of the essence of these values, and especially the way to implement them, can be a source of serious conflicts in the performance of daily tasks by the parents of the student and the teachers. It is necessary to reveal these conflicts and try to resolve them.

- Beliefs of parents and teachers about the role of both environments (family and school) in raising a child and their mutual dependence. A condition for a satisfying relationship is to learn about each other's beliefs and try to make expectations real.

- Emotional (from hostility to mutual respect) attitude of entities towards each other. The intensification of negative emotions can prevent or seriously hinder establishing and maintaining a partnership. Self-awareness of entities in terms of experienced emotions and their sources, as well as the impact on the shaped relationship is important for building a partnership.

- The communication competence of entities serving for the exchange of information and mutual intentions combined with readiness to engage in dialogue are a tool for building a partnership of parents and teachers.

Modern researchers of school reality are expected not only to reveal the imperfections of school practices and formulate normative recommendations, but above all to conduct positive research to strengthen the participating entities and support them in the process of change.

\section{Bibliography}

Bidziński K., Naukowo-metodyczne wspieranie rozwoju szkoty - urzeczywistnianie idei edukacji włączającej, [in:] Człowiek w przestrzeni edukacyjnej wspótczesnego świata, ed. E. Asmakovets, S. Koziej, Wydawnictwo Uniwersytetu Jana Kochanowskiego, Kielce 2017, p. 120-132. 
Charmaz K., Teoria ugruntowana. Praktyczny przewodnik po analizie jakościowej, Wydawnictwo Naukowe PWN, Warsaw 2009.

Christenson, S.L., The Family-School Partnership: An Opportunity to Promote the Learning Competence of All Students. "School Psychology Review", 02796015, 2004, Vol. 33, no. 1, p. 83-104.

Janke A., Kawula S., Stosunki rodziny i szkoty. Integracja i syntonia, [in:] Pedagogika rodziny: obszary i panorama problematyki, ed. S. Kawula i inni, Wydawnictwo Adam Marszałek, Toruń 2006, p. 219-262.

The Constitution of the Republic of Poland, art. 48, Journal of Law of 1997, no. 78, item 483 as amended

Kubinowski D., Jakościowe badania pedagogiczne. Filozofia. Metodyka. Ewaluacja, Wydawnictwo Uniwersytetu Marii Curie Skłodowskiej, Lublin 2010.

Lisek-Michalska J., Badania fokusowe. Problemy metodologiczne i etyczne, Wydawnictwo Uniwersytetu Łódzkiego, Łódź 2013.

Mendel M., Jak organizować wspótprace z rodzicami, [in:] Klocki autonomiczne w szkole, ed. M. Mendel, Gdańskie Forum Oświatowe, Gdańsk 1999.

Mendel M., Nauczyciel z uczniem, rodzicami i lokalna społecznością. Koncepcje partnerstwa edukacyjnego, [in:] Pedagogika wczesnoszkolna - dyskursy, problemy, rozwiazania, ed. D. Klus-Stańska, M. Szczepska-Pustkowska, Wydawnictwa Akademickie i Profesjonalne, Warsaw 2009, p. 185-223.

Pilecka Wł., Perspektywa systemowo-ekologiczna, [in:] Dziecko ze specjalnymi potrzebami edukacyjnymi w drodze ku dorostości, eds. Wł. Pilecka, M. Rutkowski, Oficyna Wydawnicza Impuls, Cracow 2009, p. 22-23.

Przewodnik po edukacji włączającej rozwój ksztatcenia i uczestnictwa w życiu szkoty, eds. T. Booth, M. Ainscow, Editor: Olimpiady Specjalne Polska, Warsaw 2011, (reedition 2012).

Regulation of the Ministry of National Education of 11 August 2017 on the requirements for schools and institutions, Journal of Laws of 2017, item 1611

The Educational Law Act, Journal of Laws of 2017 item 59 as amended

Internet sources

Epstein J. L., School and Family Partnerships. Report No. 6, Center on Families, Communities, Schools, and Children's Learning, Johns Hopkins University, Baltimore, 1992, 32 pp. https://files.eric.ed.gov/fulltext/ED343715.pdf [23 July 2018].

Lasater K., Parent-Teacher Conflict Related to Student Abilities: The Impact on Students and the Family-School Partnership, "School Community Journal", 2016, Vol. 26, No. 2, s. 237-262, http://www.schoolcommunitynetwork.org/SCJ.aspx [29 July 2018]. 
Van Voorhis F.L., Maier M.F., Epstein J.L., Lloyd Ch.M., The Impact of Family Involvement on the Education of Children Ages 3 to 8: A Focus on Literacy and Math Achievement Outcomes and Social-Emotional Skills, MDRC. 2013. http://dev.mdrc.org/sites/default/files/The_Impact_of_Family_Involvement _FR.pdf [10 May 2019]. 